\title{
Environmental Management and Corporate Social Responsibility Practices of Small and Medium-sized Enterprises
}

${ }^{1}$ Prasanta Kumar Dey (p.k.dey@ aston.ac.uk), ${ }^{1}$ Nikolaos E. Petridis (‥petridis@ aston.ac.uk),

${ }^{4}$ Konstantinos Petridis (k.petridis@uom.edu.gr), ${ }^{2 *}$ Chrisovalantis Malesios (malesios@agro.duth.gr), ${ }^{3}$ Jonathan Daniel Nixon (ac2569@ coventry.ac.uk), and ${ }^{5}$ Sadhan Kumar Ghosh (sadhankghosh9@gmail.com)

(c) 2018, Elsevier. Licensed under the Creative Commons Attribution-NonCommercial-

NoDerivatives 4.0 International

http://creativecommons.org/licenses/by-nc-nd/4.0/

\footnotetext{
${ }^{1}$ Aston University, Birmingham B4 7ET, United Kingdom

${ }^{2}$ Department of Rural Development, Democritus University of Thrace, Greece

${ }^{3}$ Coventry University, Priory Street, Coventry CV1 5FB, United Kingdom

${ }^{4}$ Department of Applied Informatics, University of Macedonia, 156 Egnatia str., 54006

Thessaloniki, Greece

*Corresponding author
} 


\title{
Environmental Management and Corporate Social Responsibility Practices of Small and Medium-sized Enterprises
}

\begin{abstract}
The main aim of this paper is to facilitate small and medium sized enterprises (SMEs) to adopt environmental management (EM) and corporate social responsibility (CSR) practices. The study reveals SMEs' motivation, pressure, targets and methods for EM and CSR practices. Additionally, the paper investigates how these variables relate to employee number, turnover and geographical locations. The outcomes of the research will add value to SMEs decision-making processes in both strategic and policy levels (e.g. supplier selection) and policymakers' initiatives to make SMEs environment and socially friendly. Although there are studies on EM and CSR practices of SMEs, they mainly focus on impact of EM and CSR practices on business performance, and SMEs' motivation for adopting EM and CSR practices in specific country. Studies that reveal SMEs' motivation, pressure, targets and methods for EM and CSR practices and their relationship with their characteristics (e.g. size, turn over, and geographical location) are scant. This research bridges this gap. Our data originates from 223 carefully selected representative SMEs in the West Midlands, UK (105) and Kolkata, India (118) covering manufacturing and process industries. The relevant data was collected using questionnaires and analysed using Analysis of Variance (ANOVA) and Multivariate Analysis of Variance (MANOVA) methods. The results reveal that perceptions of SMEs' motivation, pressure, targets and methods of EM and CSR practices vary considerably with respect to size, turn over and geographical location. The findings are significant to policymakers, client organizations and individual SME for improving EM and CSR practices.
\end{abstract}

Key Words: Environmental management, Corporate social responsibility, SMEs, Developed/emerging economies.

\section{Introduction}

Small and medium sized enterprises (SMEs) make up around 90\% of the world's businesses and they employ $50-60 \%$ of the world's population (Raynard and Forstater, 2002). Varying by country, SME definition is dependent of the size of the enterprise (e.g. the number of employees, annual sales, assets, or any combination of these). In the EU, a business with a headcount of fewer than 250 is classified as an SME. The European system also takes into account a business' turnover 
rate and its balance sheet (Commission Recommendation, 2003). SMEs in India are called micro, small and medium enterprises (MSMEs) with not more than 250 employees. Sustainability is the major challenge of today's SMEs (Longoni and Cagliano, 2015). Although there are studies on larger organisations, sustainability studies of SMEs are comparatively less (we refer the interested readers to Johnson and Schaltegger, 2016 for a critical review on the subject).

Environmental management (EM) and corporate social responsibility (CSR) are typically thought of as the commitment by businesses to act ethically, contribute to economic growth and improve the quality of life for employees and their families as well as the local community and wider society (WBCSD, 1999). The barriers for SMEs is that EM and CSR practices overall are typically thought of as expensive, even when cost reduction benefits are highlighted to them. Therefore, environmental performance of SMEs is an area of concern (Lee and Klassen, 2008). Furthermore, a large proportion of SMEs are unaware that good sustainability (right combination of economic, environmental and social aspects) can improve operational efficiencies substantially (Pil and Rothenberg, 2003). SMEs often lack resources, finances, time and knowledge to implement environmental and social improvement measures. In comparison, it is easier for larger businesses to invest in CSR and their long term benefits. Zorzini et al. (2015) review socially responsible sourcing.

In western counties, there has been a drive from governments to engage with SMEs on the topics of EM and CSR. South Australian construction organisations have adopted reverse logistics practices across their supply chain (Chileshe et al., 2016). The rationale being that SMEs combined have a major impact on the environment and are often well placed to engage with communities (Castka et al., 2004). Longo et al. (2005) investigate CSR of SMEs in Italy finding most businesses to be socially responsible because they believe it results in company growth. Graafland et al. (2003) examine how SMEs implement CSR in the Netherlands. Worthington et al. (2006) study UK small Asian businesses' perceptions and involvement with CSR, finding religious motivations to be highly influential. Aragón-Correa et al. (2008) evaluate the strategic characteristics of SMEs. The effectiveness of the organisational and environmental factors has been also examined by Tung et al. (2014). The UK Environment Agency studied the environmental practices of SMEs from 2002 to 2009 (NetRegs SME Environment surveys, 2014), finding that recycling rates among SMEs have 
increased from $42 \%$ to $84 \%$. However, by 2009 , only $18 \%$ of SMEs assessed their environmental impact and $11 \%$ carried out a programme of environmental improvements. Revell and Blackburn (2007) try to establish why SME managers are resistant to improving environmental performance by interviewing 40 SMEs in the UK's construction and restaurant sectors. They conclude that SMEs suffer from a lack of eco-literacy, having a negative perception of the business case for sustainability and a lack of pressure from customers and the whole supply chain. Biondi and Iraldo (2002) suggest that environmental innovation will be best achieved through strong networking (See also Lawrence et al., 2006). Masurel (2007) interviews 57 printing firms in the Netherlands and finds that motivation for improving environmental performance is largely driven by a result of improved working conditions, followed by satisfying legislation. Gadenne et al. (2009) highlight that businesses are willing to adopt environmental practices as a result of legislation; however, they are unaware of the benefits. Other research conducting similar surveys have found conflicting motivations as to why SMEs consider the EM and CSR, e.g. Lawrence et al. (2006), Williamson and Lynch-Wood (2001), Piercy and Rich (2015) and Hsu et al. (2016).

As regards developing countries, The United Nations Industrial Development Organization (UNIDO) reports that Indian businesses have traditionally practiced CSR for purely philanthropic reasons as there is minimal state welfare. They do note that this is shifting towards western style CSR by measuring and managing environmental and social impact (Raynard and Forstater, 2002). A more recent report by the Confederation of Indian Industry (2013) also suggests that CSR is becoming more strategic in nature than just philanthropic. Ciliberti et al. (2008) investigate the obstacles for integrating CSR in SMEs in developing countries, finding there to be a range of issues. These include lack of knowledge on legislation and laws, cultural differences, low interest by companies, poor communication and corruption.

Although the prior studies predominantly look at the impact of SMEs adopting EM and CSR practices, studies on explicit correlation between SMEs' EM and CSR practices characteristics (e.g. motivation, pressure, targets and methods) and variables such as size, turn over and geographical location are limited. Additionally, since the previous research has returned contradictory results, further research into environmental management and CSR practices of SMEs is desired. Moreover, to 
the authors' knowledge, no study has compared the social and environmental management practices of SMEs in developed and emerging economies. Knowledge on this topic is important as the extended supply chains of many SMEs in western countries are now integrated with SMEs in developing countries. The rapid developments being made in many countries' infrastructure also present an opportunity to implement best practices for improving environmental and social performance of SMEs. Furthermore, recent internationally legally binding environmental targets, such as greenhouse gas emission reductions, have increased the importance of EM and CSR agendas among SMEs. SMEs in varied geographical locations may learn from each other's experience. This study aims to address these gaps in the research by establishing and comparing the current situation with SMEs' environmental management and CSR practices in developed and emerging economies, by using data from the UK and India. In particular, we employ data from specific regions of both the countries that share certain common characteristics, such as number and type of SMEs. The UK data have been collected from the county of West Midlands, whereas the Indian data are from Kolkata, West Bengal. Both regions are industrial areas and have a long history in manufacturing.

These two countries SMEs are selected as typical cases of SMEs in developed and emerging economies so as to study the similarities and differences of EM and CSR practices with respect to motivation, pressure, targets and methods. The total number of SMEs in the UK is around 5.6 million; they employ approximately 15.8 million people and generate almost half of the country's annual turnover. In 2002, the UK Environment Agency reported that UK SMEs produce 60\% of the nation's commercial waste and 8 out of 10 major pollution incidents (Environment Agency, 2002). Nevertheless, in 2009, 91\% of UK SMEs still believed that their activities were not impacting the environment (NetRegs SME Environment surveys, 2014) and research shows that the level of engagement among SMEs around the globe in CSR and environmental management practices was extremely variable.

Employing close to $40 \%$ of India's workforce and contributing $45 \%$ to India's manufacturing output, SMEs play a critical role in generating millions of jobs, especially at the low-skill level. The country's 13 million SMEs account for $40 \%$ of India's total exports. However, $40-50 \%$ of industrial pollution in Asia Pacific region is done by SMEs. 
The above discussion formulates the following two research questions - What are the motivation, pressure, targets and methods for SMEs to adopt EM and CSR practices, and - Whether constructs for EM and CSR practices (i.e. motivation, pressure, targets and methods) vary across geographical locations (developed and emerging economies), and whether employee number and, turn over have association with EM and CSR practices. The research questions are addressed through six hypotheses that we test in this paper. Of the whole range of diverse and randomly chosen potential factors for explaining the differences in EM and CSR performance of SMEs, we narrow our hypotheses to associations between EM and CSR practices with basic measurable characteristics of SMEs, such as the number of employees (size), turnover, and geographical locations. These specific characteristics have been chosen due to their direct connection to environmental management and CSR practices. Turnover and employee number are directly connected to the SMEs' resources, whereas environmental management and CSR practices depends on resource deployments. The issue of firm size and its effect on CSR has been already identified in the literature as vital and unexamined (Madden et al., 2006). Therefore, turnover and number of employees are the most suitable variables through which environmental management and CSR practices might vary. In addition, environmental management and CSR practices are closely connected to the socio-economic state and culture of specific geographical location, since, for example, organizations in specific geographical location could be more environmentally concerned than others due to various reasons.

Accordingly we formulate the following hypotheses:

Hypothesis 1 (H1): “SMEs' Environment management (EM) practices vary with number of employees in each SME of both developed / emerging economies."

Hypothesis 2 (H2): "SMEs' EM practices vary with turnover of each SME of both developed / emerging economies.” 
Hypothesis 3 (H3): "Pressure from and image of SMEs for implementing environmental management practices vary with number of employees in each SME of both developed / emerging economics."

Hypothesis 4 (H4): "SMEs' views towards Corporate Social Responsibility (CSR) vary with number of employees in each organisation and their geographical location."

Hypothesis 5 (H5): "SMEs views towards CSR vary with turnover of each organisation and its geographical location."

Hypothesis 6 (H6): "SMEs Social and Ethical responsibility and business in the community vary with number of employees, geographical location and turnover."

The next section outlines the methodology to test the hypotheses and reveal the answers to the research questions. In Section 3, the results of hypotheses testing have been delineated along with answers to the research questions. Section 4 summarises the findings, discusses theoretical and practical contributions, and states the scope for further research. Section 5 concludes the paper with a few propositions.

\section{Research methodology}

\subsection{Construction of the questionnaire and selection of sample size}

This section provides an overview of the protocol followed for conducting the survey, questions developed, type of responses gathered and selection of sample size of the survey. Specifically, an interview protocol was formed and a survey has been designed and conducted to gather both quantitative and qualitative data on EM and CSR practices of SMEs in the UK and India. Firstly, a workshop was organized with the involvement of selected researchers and owners/managers of several British SMEs to derive a suitable questionnaire for achieving the objectives of the study. Secondly, an initial pre-sample survey was conducted on SMEs across the two countries (the UK and 
India). SME contacts in India have assisted in adapting the questionnaire and constructs to the country framework. The final data has been collected from 105 SMEs in the West Midlands, UK and 118 SMEs in Kolkata, India. All these SMEs are either from manufacturing or process industries that generally impact the environment more than SMEs in other industries. SMEs of two regions in the UK and India (a developed and an emerging economy) are considered to examine the influence of geographical locations and get the perspectives of varied economies.

The survey data collected from managerial staff of SMEs in West Midlands county, UK and Kolkata, India are compared with the specific aim of providing answers to research questions such as what are the motivating factors for and pressure to SMEs to implement EM and CSR strategies, what EM and CSR targets are SMEs implementing, how are SMEs measuring and monitoring EM and CSR performance and how does size (employee number and turnover) and geographical location influence SMEs' views towards the EM and CSR practices.

For selecting the appropriate sample size for deriving valid inferences we have utilized simple random sampling (SRS) for our sample framework. In particular, for sample size selection, the following SRS formula was used:

$$
n=\frac{t^{2} \hat{p}(1-\hat{p})}{e^{2}}
$$

where with $\hat{p}=\frac{\sum_{i=1}^{n}\left(p_{i}\right)}{n}$ we denote the estimate of population proportion that share a certain characteristic on one of the (categorical) variables in the survey, and $e$ is the proportion of error we are prepared to accept between the sampling proportion and the unknown proportion of the population (we accept that $e=10 \%$ ). Pre-sampling was also conducted on an initial sample of 40 SMEs (20 from the UK and 20 from India) in order to estimate $p$ under the desired selected error $e$, while the rest are estimated with a greater accuracy than was initially defined. The dichotomous variable presenting the largest sample size, showed a proportion of approximately $p=0.5$. Finally, $t$ denotes the value from the standard normal distribution reflecting the confidence level that will be used $(t=1.96$ for a 95\% 
confidence level). Hence, according to the above formula, the final sample size was approximately 96 SMEs for each country.

Over 300 survey questionnaires have been sent to selected SMEs in each country from alternative sectors and of varying size with respect to turnover and number of employees, with a focus on manufacturing and process industries to randomly selected SMEs from the selected industrial regions in the UK and India. Responses have been received from 105 SMEs in the West Midlands, UK and 118 SMEs in Kolkata, India, exceeding the level of 96 questionnaires. Qualitative interviews to selected SMEs were also undertaken for validating the responses collected. Respondents include the managers, owners and directors of the SMEs, adding the restriction of having at least a 15-year experience within the company. The response rate was close to 35\%. Criteria for the survey have been developed by working collaboratively with British and Indian industry experts, reviewing the literature and conducting pilot interviews with SMEs. The survey questions have been established from the reviewed literature and by working closely with SMEs and consultants. Appendix A depicts EM and CSR practices constructs that this research considers for detailed analysis (Table A1). Some questions require a single answer whereas others are scored on a scale system. Descriptions on the types of questions asked and sources of comparable questions used in other studies are provided in Appendix B (Table B1). The full survey questionnaire can be found in Appendix C. The items of the questionnaire that have been considered for the analysis of the present paper are scored on a 5- point Likert scale.

\subsection{Statistical analysis}

In order to assess the effects of the various explanatory variables on the EM and CSR practices of SMEs in the UK and India we have used both descriptive statistics and statistical modelling inference techniques. Hence, the analysis is divided into two parts: (i) the constructs of EM and CSR are analysed for each country using descriptive statistics, and (ii) the associations of employee number, turnover and geographical location with SMEs' views towards the EM, and CSR 
practices using analysis of variance (ANOVA) ${ }^{1}$ (Dobson and Barnett, 2008; Faraway, 2005). The selection of ANOVA method was appropriate due to the categorical nature of the independent variables, i.e. No of employees (coded as the categories: less than 10, from 10 to 100, from 100 to 250 and more than 250 employees), turnover (coded as: less than 1 million, from 1 to 10 millions, from 10 to 50 millions and more than 50 millions) and geographical location (India / the UK). In addition, multivariate analysis of variance (MANOVA) is utilized in the case where the dependent variable is a combination of a set of correlated observed items (Frane, 2015). For the MANOVA models, the cronbach's alpha test for reliability has been previously applied for checking of the reliability of the analysis conducted. In order to assess the significance of the individual predictors on the dependent variables we follow a forward selection model and covariate comparison scheme, in which for each model only one aspect is allowed to vary each time and then this model is compared with the previous one through F-test. Specifically, we start from the null model (which includes only an intercept as explanatory variable) and sequentially add all covariates. Through this procedure, the best among the nested models is selected and presented in the results section. Data have been analysed through SPSS statistical software (IBM Corp. Released, 2012).

\section{Results}

\subsection{Descriptive analysis results}

The survey results show that the motivations for SMEs in the UK and India to consider their EM practices are very similar. However, the motivations for SMEs in these two countries to adopt CSR practices are quite different. In the UK and India, 90\% and $81 \%$ respectively of businesses believe that they consider their impact on the environment. The main incentive for SMEs to consider the environment is to satisfy legislation. Moral duty is regarded as the second most important reason. The majority of SMEs in the UK and India believe that they consider CSR. The survey results indicate that companies in the UK implement CSR for a range of reasons. Whereas SMEs in India consider moral duty and firm image to be the main reasons, with other motivations considered to be of

\footnotetext{
${ }^{1}$ In case of more than one dependent variables, multivariate analysis of variance (MANOVA) is correspondingly utilized.
} 
relatively low importance (see Figure 1). In particular, SMEs in India are well behind in satisfying legislation as regards CSR implementation.

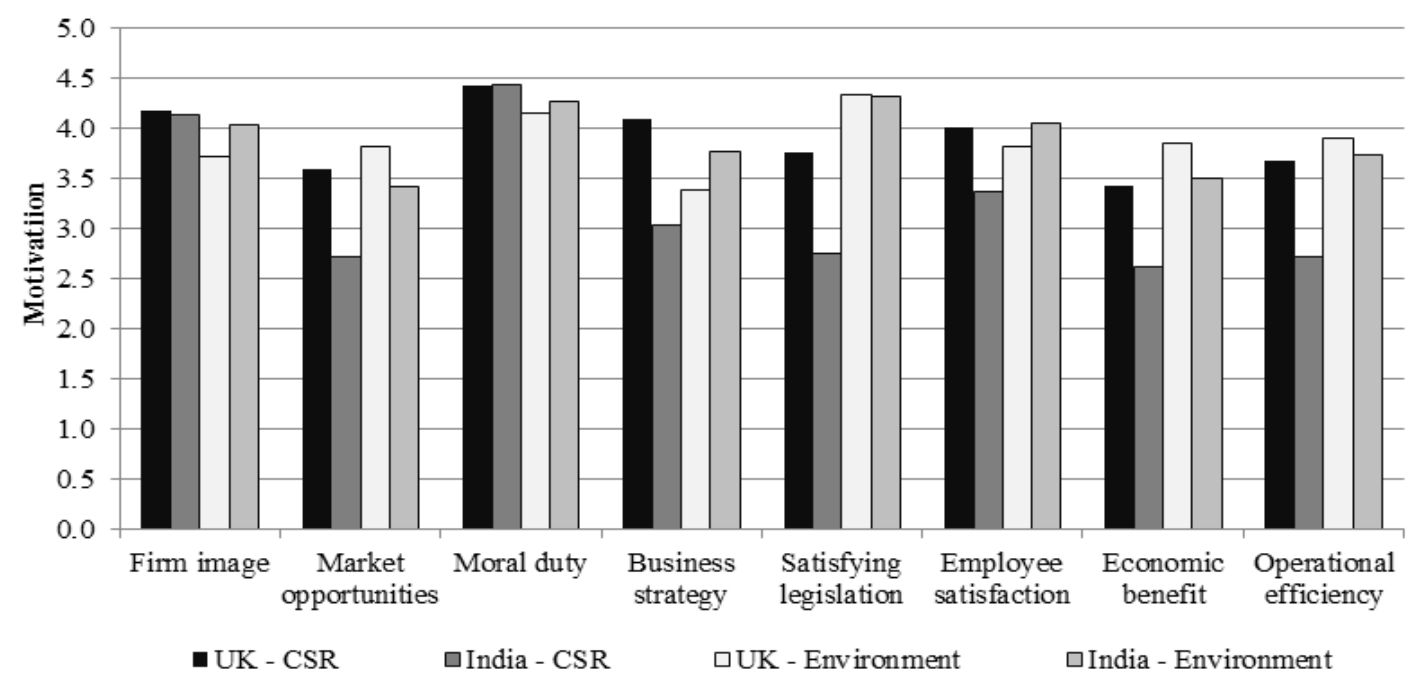

Figure 1: Average motivations for SMEs in the UK and India to consider their EM and CSR practices.

Pressure to consider EM and CSR practices is applied on SMEs from a number of alternative sources. The trend in the amount of pressure received from these different sources is similar for SMEs in the UK and India. In both the countries, the greatest amount of pressure to consider the environment and climate change comes from the government. In comparison, the pressure received from the government to consider CSR is lower (see Figure 2). Interestingly, shareholder and parent companies apply minimal pressure on SMEs to incorporate CSR into their businesses strategies.

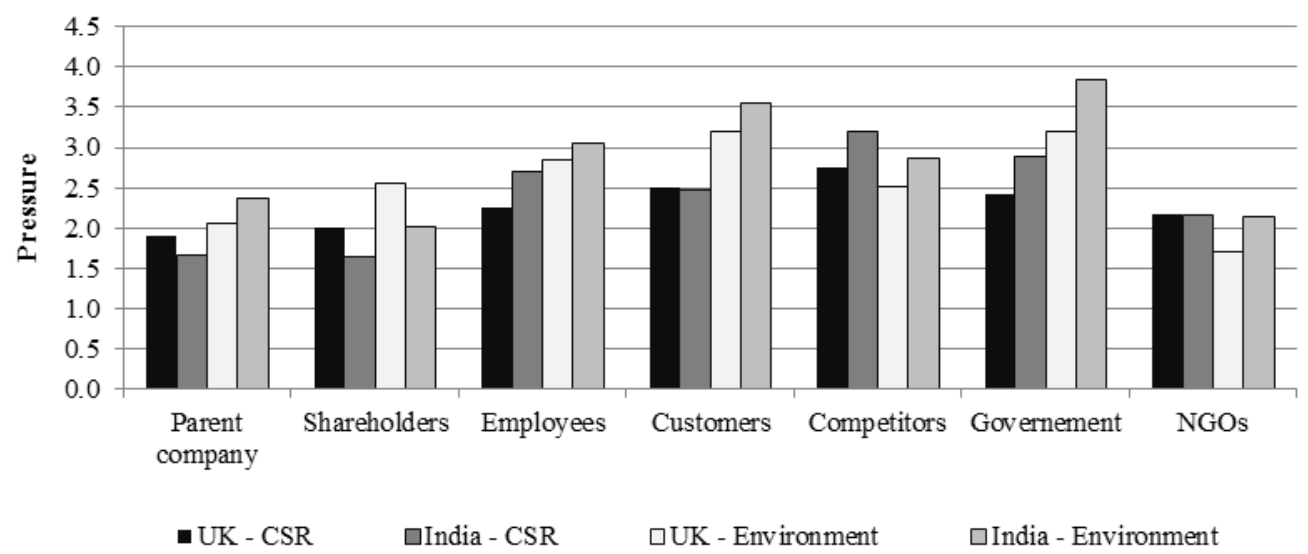

Figure 2: Average level of pressure applied by alternative groups on SMEs in the UK and India to make them consider their EM impact and CSR. 
As regards the EM practices and monitoring methods being used by SMEs, it is surprising that in comparison to the UK SMEs, more businesses in India have environmental targets, yet fewer have methods for monitoring their environmental performance (see Figures 3 and 4).

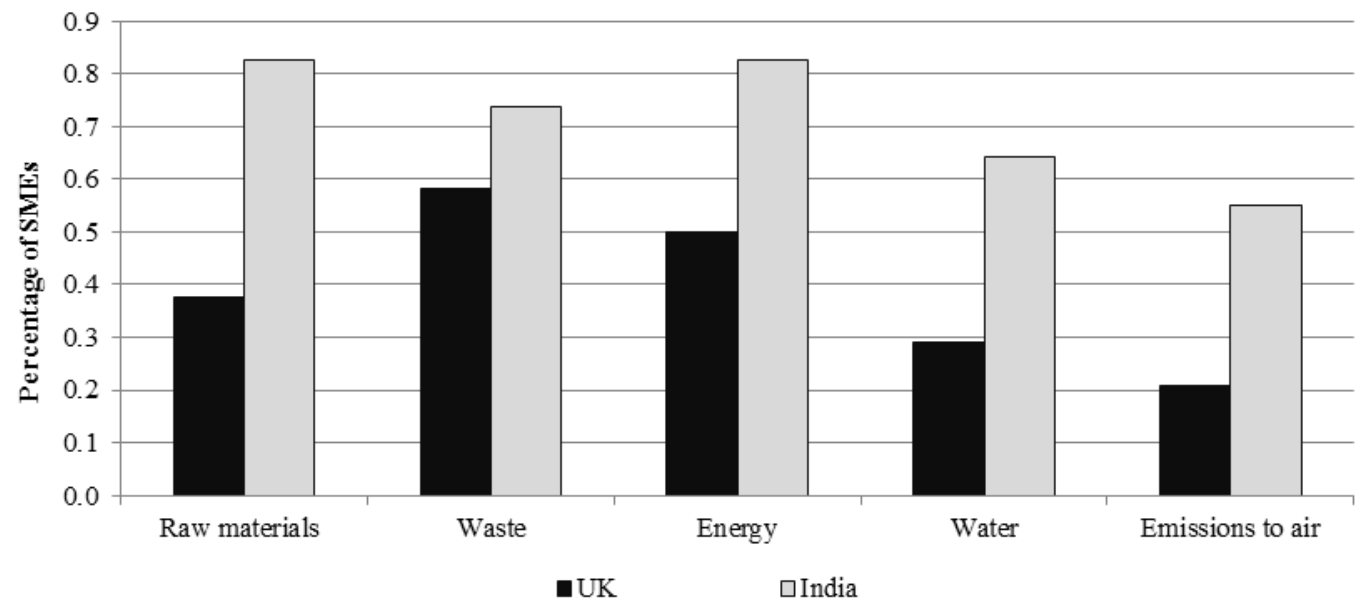

Figure 3: Percentage of SMEs in the UK and India with environmental targets.

Whilst energy and waste targets are being implemented by the majority of SMEs, raw material usage is particularly high on the agenda in India with over $80 \%$ of business implementing targets. In comparison, only $38 \%$ of SMEs in the UK report having raw material targets. In both the countries, water and emission targets are in general less implemented, especially in the UK. $76 \%$ of the UK SMEs report having a recycling program and staff training on environmental practices. In comparison, only $20 \%$ and $50 \%$ of SMEs in India reported having recycling and training programs respectively. Whilst $48 \%$ of SMEs in the UK have ISO 14001, only $10 \%$ of the SMEs in India have this certification. The percentages of SMEs with environmental audits and methods of formal reporting are also low in India. 


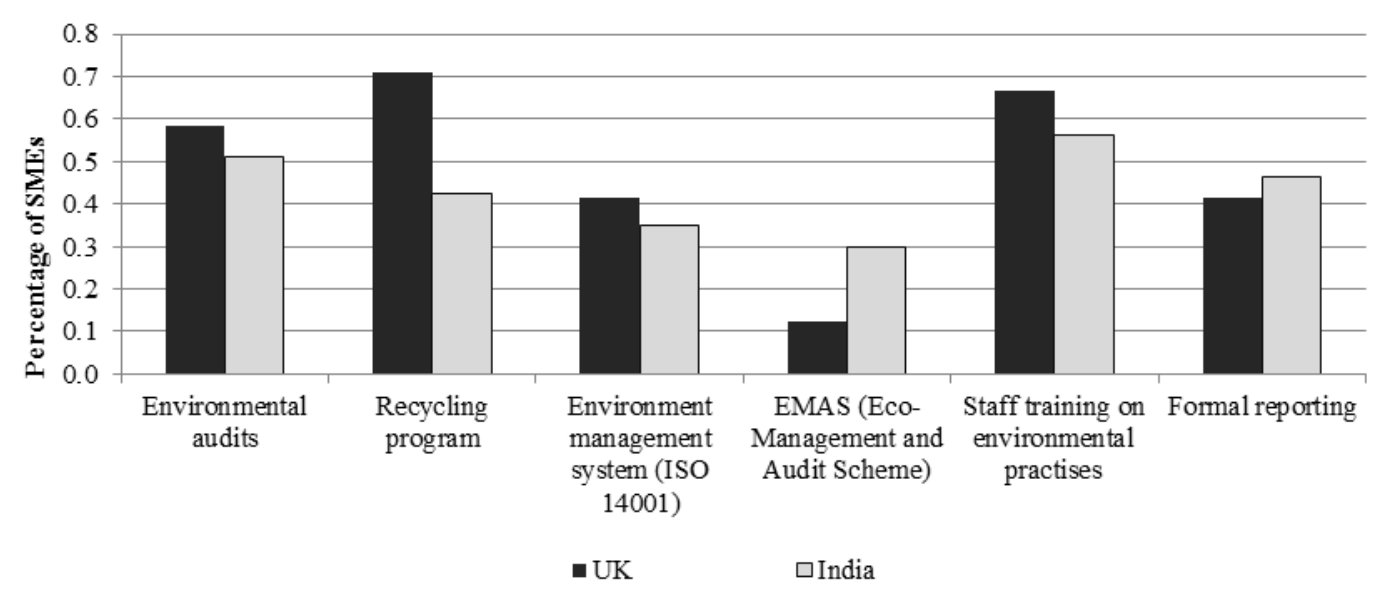

Figure 4: Percentage of SMEs in the UK and India with monitoring of their environmental performance.

Next, as regards the attempt to identify the most dominant drivers for SMEs to implement EM and CSR practices, Table 1 presents the descriptive statistics of the managers' responses referring to their rankings of EM drivers. Data analysis reveals that the main motivating factors for EM practices are 'Satisfying legislation' and 'Moral duty' (mean rankings: 4.32 and 4.22 respectively). On the contrary, pressure for addressing environmental issues is mainly driven by the governments (mean ranking: 3.6) whereas less pressure is due to NGOs (mean ranking: 1.98).

Table 1: Descriptive statistics for EM drivers within SMEs.

\begin{tabular}{cccc}
\hline Question & Mean & $\begin{array}{c}\text { Standard } \\
\text { Deviation }\end{array}$ \\
\hline & Parent company & 2.27 & 1.97 \\
Shareholders & 2.21 & 1.89 \\
& Employees & 2.98 & 1.55 \\
Customers & 3.41 & 1.46 \\
& Competitors & 2.74 & 1.52 \\
Government & 3.60 & 1.20 \\
NGOs & 1.98 & 1.67 \\
\hline & Firm image & 3.92 & 0.92 \\
& Market opportunities & 3.56 & 1.21 \\
Moral duty & 4.22 & 0.81 \\
& Business strategy & 3.63 & 1.23 \\
& Satisfying legislation & 4.32 & 0.84 \\
Improved working & 3.97 & 1.10 \\
conditions & 3.63 & 1.00 \\
\hline
\end{tabular}


In Table 2, the descriptive statistics of questions belonging to the wider Corporate Social Responsibility (CSR) category are presented. Questions exhibiting the highest mean values are "the motivation of moral duty" (4.43) and "the motivation of firm image" (4.14). On the other hand, the factors that the SMEs consider of low importance for CSR practices are belonging to the pressure category, i.e. "pressures from the parent company" and "pressures from shareholders".

From the descriptive analysis, an interesting finding is that most SMEs in the UK have ethics committees but do not have ethical training. The opposite occurs in India, with most businesses having ethical training and no committee.

Table 2: Descriptive statistics for CSR drivers within SMEs.

\begin{tabular}{|c|c|c|c|}
\hline Category & Question & Mean & $\begin{array}{l}\text { Standard } \\
\text { Deviation }\end{array}$ \\
\hline \multirow{9}{*}{ : } & Firm image & 4.14 & 0.84 \\
\hline & Market opportunities & 2.94 & 1.51 \\
\hline & Moral duty & 4.43 & 0.79 \\
\hline & Business strategy & 3.29 & 1.58 \\
\hline & Satisfying legislation (rules and & & \\
\hline & regulations) & 3.00 & 1.86 \\
\hline & Employee satisfaction & 3.52 & 1.30 \\
\hline & Economic benefit & 2.81 & 1.66 \\
\hline & Operational efficiency & 2.96 & 1.63 \\
\hline \multirow{7}{*}{ 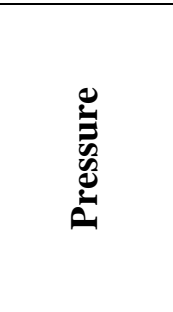 } & Pressure from parent company & 1.72 & 1.42 \\
\hline & Pressure from shareholders & 1.73 & 1.45 \\
\hline & Pressure from employees & 2.58 & 1.41 \\
\hline & Pressure from customers & 2.48 & 1.46 \\
\hline & Pressure from competitors & 3.08 & 1.61 \\
\hline & Pressure from government & 2.77 & 1.62 \\
\hline & Pressure from NGO & 2.16 & 1.55 \\
\hline \multirow{9}{*}{ 己ֶ) } & My organization is aware of its social & & \\
\hline & $\begin{array}{l}\text { responsibilities } \\
\text { Business success is linked to CSR }\end{array}$ & $\begin{array}{l}4.07 \\
2.30\end{array}$ & $\begin{array}{l}0.96 \\
1.14\end{array}$ \\
\hline & CSR is equally important as profits & 2.81 & 1.29 \\
\hline & CSR should be integrated into core & & \\
\hline & organizational strategies & 2.82 & 1.29 \\
\hline & Customers are interested in our CSR & 2.36 & 1.27 \\
\hline & SMEs cannot afford to be socially & & \\
\hline & responsible & 2.94 & 1.33 \\
\hline & SMEs cannot impact society & 2.10 & 1.19 \\
\hline
\end{tabular}




\subsection{Statistical analysis results using ANOVA}

The results on the investigation for associations between the EM and CSR practices with the explanatory variables of number of employees, turnover and geographical location of SMEs in the two countries, as stated through the five research hypotheses (H1-H5), are presented in this section. In addition, we also examine connections between SMEs' ethical and social responsibility with the latter explanatory variables (H6). In doing this, ANOVA is utilized, treating as dependent variables the specific items of EM and CSR measured from the survey, and their relation with the above mentioned explanatories. Note that for saving space, only the statistical significant results are presented in the following tables. Analytically, the results associated with testing hypothesis $\mathrm{H} 1$ are shown in the following table (Table 3).

Table 3: Two-way ANOVA estimates for EM questions using number of employees, geographical location and their interaction as independent variables

\begin{tabular}{|c|c|c|c|c|}
\hline Category & Dependent & Independent & SS & F - statistic \\
\hline \multirow{4}{*}{ 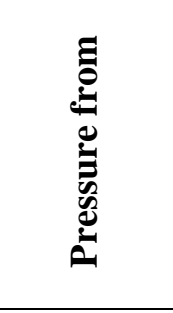 } & $\begin{array}{c}\text { Parent } \\
\text { company }\end{array}$ & No of employees & 32.7 & $3.89^{* *}$ \\
\hline & Customers & No of employees & 21.2 & $2.85^{* *}$ \\
\hline & Competitors & $\begin{array}{l}\text { No of employees } \\
\text { geographical location }\end{array}$ & $\begin{array}{c}20.12 \\
8.25\end{array}$ & $\begin{array}{l}3.42^{* *} \\
4.21^{* *}\end{array}$ \\
\hline & $\begin{array}{c}\text { Pressure } \\
\text { groups }\end{array}$ & $\begin{array}{l}\text { No of employees } \\
\text { geographical location }\end{array}$ & $\begin{array}{c}33.45 \\
6.20 \\
\end{array}$ & $\begin{array}{l}6.59^{* * *} \\
3.66^{* *}\end{array}$ \\
\hline \multirow{2}{*}{ 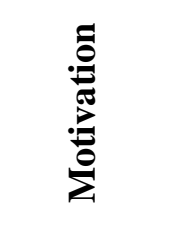 } & Moral duty & $\begin{array}{c}\text { No of employees } \times \text { geographical } \\
\text { location }\end{array}$ & 5.29 & $3.71^{* *}$ \\
\hline & $\begin{array}{l}\text { Improved } \\
\text { working } \\
\text { conditions }\end{array}$ & $\begin{array}{c}\text { No of employees } \times \text { geographical } \\
\text { location }\end{array}$ & 8.54 & $3.16^{* *}$ \\
\hline
\end{tabular}

Table 3 presents the results for the estimates of two-way ANOVA using as dependent variable the opinion of questions on EM practices against number of employees, geographical location and their interaction. Managers in smaller SMEs tend to have a different opinion in regards to the pressures from a parent company $[\mathrm{F}(3,36)=3.89, \mathrm{p}<0.05]$. The perception on pressure from customers for adopting CSR varies with the size of the $\operatorname{SMEs}[\mathrm{F}(3,37)=2.85, \mathrm{p}<0.1]$. Competition is considered another point of opinion diversification due to the fact that the managers of SMEs have different perceptions according to the size of the firm $[\mathrm{F}(3,37)=3.42, \mathrm{p}<0.05]$ for which they work and the geographical region where the firm operates $[\mathrm{F}(1,37)=4.21, \mathrm{p}<0.05]$. Managers in firms of 
different size which operate in different geographic location tend to diversify their evaluation towards moral duty $[\mathrm{F}(2,38)=3.71, \mathrm{p}<0.05]$. This statistically significant difference between managers in firms operating in different geographical regions is due to the fact that managers in firms which operate in India with 100 to 250 employees consider moral duty as a more important factor than those in the UK (see Figure 5_a). Furthermore, the managers of firms which operate in India and the UK SMEs seem to have different evaluations towards improved working conditions $[F(2,38)=3.16$, $p<$ 0.05]. The interaction plot as seen in Figure 5_b provides some evidence for this differentiation. Finally, firms with more than 250 employees seem to present high values of moral duty while no Indian firms have been reported in this category.
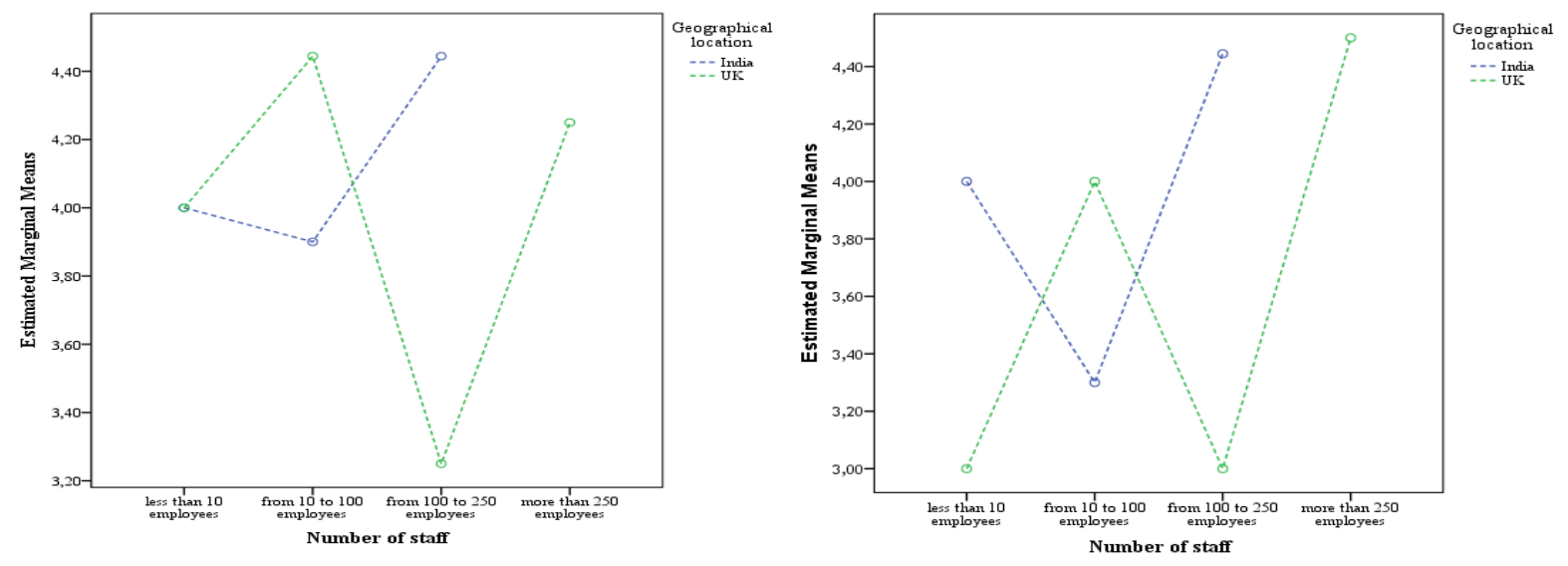

(a)

(b)

Figure 5: Interaction plot for (a) moral duty and (b) improved working conditions according to number of staff and geographical location.

The results of the investigation of the hypothesis 2 are provided in Table 4.

Table 4: Two-way ANOVA estimates for EM questions using turnover, geographical location and interaction as independent variables

\begin{tabular}{ccccc}
\hline Category & Dependent & Independent & SS & F - statistic \\
\hline $\begin{array}{c}\text { Pressure } \\
\text { from }\end{array}$ & Pressure groups & $\begin{array}{c}\text { Turnover } \times \\
\text { Geographical location }\end{array}$ & 18.99 & $4.25^{* *}$ \\
\hline Motivation & Satisfying legislation & Turnover & 5.10 & $2.47^{*}$ \\
${ }^{* * * *}: \mathrm{p}<0.01,{ }^{* *}: \mathrm{p}<0.05,{ }^{*}: \mathrm{p}<0.10$ & & &
\end{tabular}


In Table 4 the results of two-way ANOVA are presented, using the survey questions related to EM practices as dependent variables and turnover, geographical location of the firm as well as an interaction of both as independent variables.

The pressure which originates from the pressure groups seems to be a point of dispute between the managers of firms with high turnover against firms with low turnover in India and UK $[F(3,37)=$ $4.25, \mathrm{p}<0.05]$ (see also Figure 6 below).

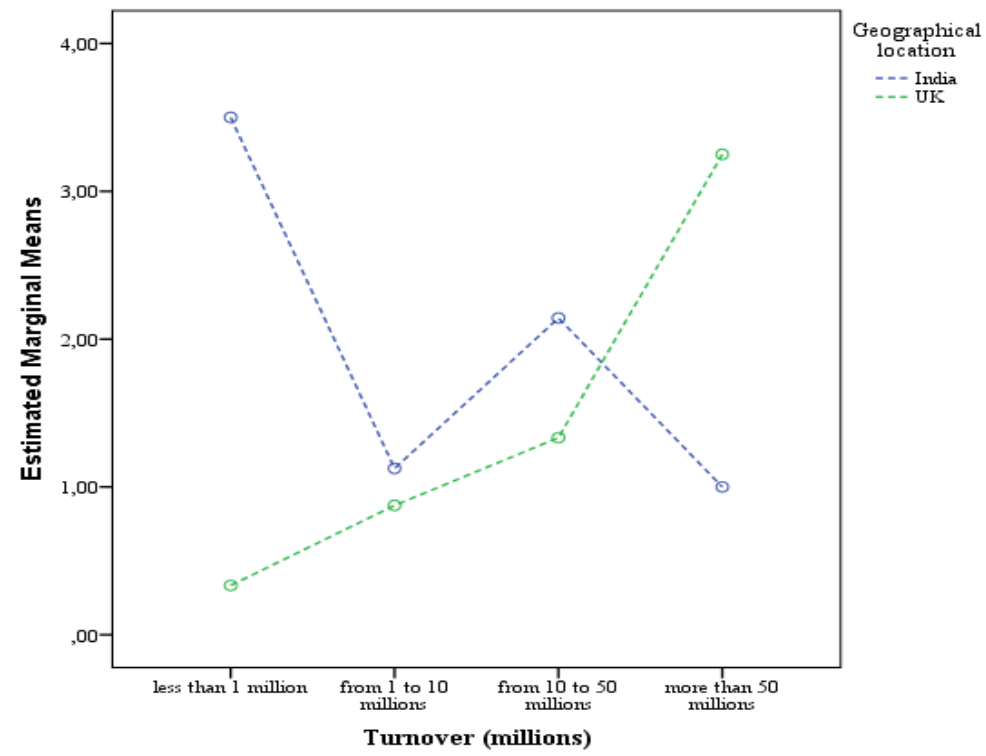

Figure 6: Interaction plot for improved working condition according to turnover and geographical location.

On the contrary the managerial staff in firms with different turnover levels tend to have different aspect towards satisfying legislation $[\mathrm{F}(3,37)=2.47, \mathrm{p}<0.1]$.

The hypothesis 3 results are shown in Table 5 .

Table 5: MANOVA results for two EM constructs.

\begin{tabular}{cccc}
\hline Dependent variable & Independent & DF & Pillai's \\
\hline \multirow{2}{*}{ Pressure from } & No of employees & 3 & $0.81^{* *}$ \\
\hline Image & turnover & 3 & $0.78^{*}$ \\
\hline${ }^{* * * *}: \mathrm{p}<0.01,{ }^{* *}: \mathrm{p}<0.05,{ }^{*}: \mathrm{p}<0.10$ & No of employees & 3 & $0.85^{*}$ \\
\end{tabular}


In order to evaluate if there is a difference in opinion regarding the direction of pressure and the image, MANOVA is conducted. The dependent variable consists of a linear combination of all questions which constitute the construct "Pressure from ....". Results indicate that managers' opinion differs according to the number of staff [Pillai's trace $=0.81, \mathrm{p}<0.05$ ] as well as the turnover of the firm [Pillai's trace $=0.78, \mathrm{p}<0.1]$. Reliability of the set of dependent variables has been checked through the Cronbach's alpha test (alpha=0.786), which gave a high reliability result. Geographical location does not affect statistically significant the opinion and neither does an interaction between number of staff or turnover with geographical location. The linear combination of all the questions which consist of the "Image" is affected by the turnover of the firms [Pillai's trace $=0.85, p<0.1$ ] (Cronbach's alpha=0.725).

Next, we examine the validity of research hypothesis 4 (Table 6).

Table 6: Two-way ANOVA estimates for CSR questions using number of employees, geographical location and interaction as independent variables

\begin{tabular}{|c|c|c|c|}
\hline Dependent & Independent & SS & F - statistic \\
\hline Firm image & No of employees $\times$ geographical location & 5.26 & $2.82^{*}$ \\
\hline Business strategy & geographical location & 9.48 & $10.51^{* * *}$ \\
\hline Satisfying legislation & geographical location & 30.08 & $20.98^{* * *}$ \\
\hline Economic benefit & geographical location & 17.27 & $11.31^{* * *}$ \\
\hline $\begin{array}{l}\text { Operational } \\
\text { efficiency }\end{array}$ & geographical location & 11.35 & $10.76^{* * *}$ \\
\hline Parent Company & No of employees & 17.28 & $2.86^{* *}$ \\
\hline Customers & No of employees $\times$ geographical location & 11.65 & $2.76^{*}$ \\
\hline Competitors & No of employees $\times$ geographical location & 12.99 & $2.65^{*}$ \\
\hline $\begin{array}{l}\text { My organisation is } \\
\text { aware of its social } \\
\text { responsibilities }\end{array}$ & No of employees $\times$ geographical location & 5.70 & $2.69^{*}$ \\
\hline $\begin{array}{l}\text { SMEs cannot afford } \\
\text { to be socially } \\
\text { responsible }\end{array}$ & No of employees $\times$ geographical location & 8.42 & $3.06^{*}$ \\
\hline $\begin{array}{l}\text { SMEs cannot impact } \\
\text { society }\end{array}$ & $\begin{array}{c}\text { geographical location } \\
\text { No of employees } \times \text { geographical location }\end{array}$ & $\begin{array}{l}3.28 \\
6.64\end{array}$ & $\begin{array}{l}3.15^{*} \\
3.18^{*}\end{array}$ \\
\hline
\end{tabular}


In Table 6 the results of the two-way ANOVA estimates are presented using as dependent variables the CSR questions and independent variables the number of employees, the geographical location as well as a combination of both.

The importance of firm image is evaluated unequally among managers who are engaged in small and big firms and are located in the UK and India $[\mathrm{F}(3,38)=2.82, \mathrm{p}<0.1]$. For the factors of business strategy, satisfying legislation, economic benefit and operational efficiency the significant difference is due to the geographical location and not to the number of employees. In all cases, the managers in the UK evaluate these aspects in a more positive way than those working for firms which operate in India. Managers in both countries have different opinions on the fact that pressure comes from customers $[\mathrm{F}(3,38)=2.65, \mathrm{p}<0.1]$ or competitors $[\mathrm{F}(3,38)=2.69, \mathrm{p}<0.1]$.

The research question 'Do SMEs views towards Corporate Social Responsibility (CSR) vary with turnover of each organisation and its geographical location?', corresponding to hypothesis 5, is analysed in Table 7.

Table 7: Two-way ANOVA estimates for CSR questions using turnover, geographical location and interaction as independent variables

\begin{tabular}{|c|c|c|c|}
\hline Dependent & Independent & SS & F-statistic \\
\hline Firm image & Turnover $\times$ geographical location & 5.41 & $3.11^{* *}$ \\
\hline Market Opportunities & geographical location & 10.85 & $4.66^{* *}$ \\
\hline Business Strategy & geographical location & 23.61 & $23.35^{* * *}$ \\
\hline $\begin{array}{l}\text { Satisfying } \\
\text { Legislation }\end{array}$ & geographical location & 35.68 & $21.37^{* * * *}$ \\
\hline Economic Benefit & geographical location & 18.63 & $10.73^{* * * *}$ \\
\hline $\begin{array}{l}\text { Operational } \\
\text { Efficiency }\end{array}$ & geographical location & 21.96 & $20.67^{* * * *}$ \\
\hline Customers & Turnover $\times$ geographical location & 16.08 & $3.14^{*}$ \\
\hline Competitors & $\begin{aligned} & \text { Turnover } \\
& \text { Turnover } \times \text { geographical location }\end{aligned}$ & $\begin{array}{l}20.13 \\
19.08\end{array}$ & $\begin{array}{l}3.61^{* * *} \\
3.42^{* *}\end{array}$ \\
\hline $\begin{array}{l}\text { CSR is equally } \\
\text { important as profits }\end{array}$ & Turnover & 18.56 & $3.50^{* *}$ \\
\hline $\begin{array}{l}\text { SMEs cannot impact } \\
\text { society }\end{array}$ & $\begin{aligned} & \text { Turnover } \\
& \text { Turnover } \times \text { geographical location }\end{aligned}$ & $\begin{array}{l}5.68 \\
8.09\end{array}$ & $\begin{array}{l}2.53^{* * *} \\
3.61^{* *}\end{array}$ \\
\hline
\end{tabular}

According to the results, importance of firm image does not seem to change over turnover of corporations or by country in which the firm operates. However it is different for managers working in firms of different turnovers in India and $\operatorname{UK}(F(3,21)=3.11, \mathrm{p}<0.05)$. Managers in India who 
work for small sized corporations (turnover less than 1 million) tend to consider a much more important factor concerning the corporate social responsibility than the managers of corporations in the UK (see Figure 6).

The contribution of market opportunities regarding the corporate social responsibility is different for the managers who work in India and the UK $(F(1,20)=4.66, p<0.05)$ as well as the opinion towards business strategy, satisfying legislation, economic benefits and operational efficiency (Table 7). On average, managers located in India tend to consider the above factors more importantly than their colleagues in the UK, regardless the size of the firm they work for.

The interaction term of geographical location and turnover is statistically significant for the opinion of the managerial staff regarding pressure from competitors $(F(3,21)=3.11, p<0.05)$. On the other hand, managers tend to disagree as far as the fact that SMEs cannot impact society depending on the size of the firm they work for $(\mathrm{F}(3,22)=2.53$, $\mathrm{p}<0.1)$. In addition, the interaction term of turnover and geographical location is also statistically significant at $5 \%$ level of significance $(\mathrm{F}(3,22)=3.61, \mathrm{p}<0.05)$. This difference has been caused by the fact that SMEs managers in the UK who work for larger sized corporations with a turnover which lies in the range of $10-50$ million tend to consider this aspect more significant than those working in corporations of the same turnover in India.

Finally, the question 'Do Business' Social and Ethical responsibility and Business in the community vary with number of employees, geographical location and turnover?' has been analysed Table 8 (hypothesis 6).

Table 8: MANOVA results for two CSR constructs.

\begin{tabular}{cccc}
\hline Dependent variable & Independent & DF & Pillai's \\
\hline Business' Social and & No Staff & 88 & $2.73^{*}$ \\
Ethical responsibility & Geographical location & 22 & $0.83^{* *}$ \\
& No Staff $\times$ Geographical & 88 & $2.87^{* *}$ \\
\hline location & Turnover & 60 & $2.55^{* * *}$ \\
Business' Social and & Geographical location & 15 & $0.73^{* * *}$ \\
Ethical responsibility & Turnover $\times$ Geographical & 60 & $2.22^{* * *}$ \\
\hline Business in the community & location & 28 & $1.04^{* * *}$
\end{tabular}




\begin{tabular}{|c|c|c|c|}
\hline membership/Certification & Geographical location & 7 & $0.39^{* *}$ \\
\hline (BITC) & $\begin{array}{c}\text { No Staff } \times \text { Geographical } \\
\text { location }\end{array}$ & 28 & $0.87^{*}$ \\
\hline Business in the community & Turnover & 28 & $1.23^{* * * *}$ \\
\hline membership/Certification & Geographical location & 7 & $0.41^{* * *}$ \\
\hline (BITC) & $\begin{array}{c}\text { Turnover } \times \text { Geographical } \\
\text { location }\end{array}$ & 28 & $0.89^{*}$ \\
\hline
\end{tabular}

In Table 8 the results of MANOVA are presented (Cronbach's alpha $=0.855)$. Mean values of construct "Business' Social and Ethical responsibility" differ statistically significant across firms with unequal number of employees $(\mathrm{p}<0.05)$ and geographical location $(\mathrm{p}<0.05)$. In addition, there is a statistically significant difference of construct's mean values within firms of unequal number of employees across different countries $(\mathrm{p}<0.05)$.

Business' Social and Ethical responsibility is affected statistically by the turnover of firms ( $p$ $<0.01)$, the country in which they operate $(\mathrm{p}<0.01)$ and between small and large firms within each country $(\mathrm{p}<0.01)$. The same pattern is observed for the construct "Business in the community (BITC) membership/Certification" (Cronbach's alpha $=0.791)$ among firms which engage unequal number of employees and operate in different countries.

\section{Discussion}

\subsection{Theoretical Implications}

This study set out to reveal SMEs' motivation, pressure, targets and methods for adopting EM and CSR practices. Additionally, it also investigates whether the constructs for EM and CSR practices (i.e. motivation, pressure, targets and methods) vary across geographical locations (developed and emerging economies), employee number, and turn over. Insight on these may help policymakers, customers and SMEs to undertake right decisions to promote environment and social friendly business practices. Current researches on SMEs' environmental and social practices are dominant on impact of environmental and social practices on their economic performance. Although there are studies on SMEs CSR practices comparing developed and emerging economies that reveal contradictory results, indicating that despite the different cultural and operational settings, the implementation of CSR 
activities by companies followed a fairly similar logic (Li et al., 2016). Our results on the other hand, at least for the vast majority of EM and CSR practices examined here, show the existence of important differences. Descriptive analysis identified that while motivation for adopting EM measures are similar in the UK and India, adopting CSR practices in the two countries are different. Highest pressure for adopting EM comes from Government whereas pressure for adopting CSR comes from customers. The analysis brings up the fact that raw material usage is of high importance in India, while only a very small percentage of SMEs in India report recycling and staff training programs in environmental practices. The UK results show that only a small percentage of SMEs have raw material usage targets, while regarding recycling programs, the UK SMEs report higher percentages compared to the ones from India. As regards CSR practices, for the UK SMEs the largest percentages are found in views that take into account awareness of organisation towards social responsibilities and integration of CSR into core organisational strategies. Finally, ISO Certification and Code of conduct are the two major monitoring methods of EM and CSR respectively for SMEs in the UK and India. Therefore, knowledge on SMEs EM and CSR practices constructs (e.g. motivation, pressure, targets and methods) help policymakers to make decisions on budgets and customers / clients to form supplier selection strategies. Additionally, individual SME could benchmark their EM and CSR practices with their peers and competitors.

Associations of SMEs size, turnover and geographical location with EM and CSR practices were studied using ANOVA (and MANOVA) analysis. The study reveals that the perceptions of SMEs in the two varied economies on EM and CSR practices vary considerably. Overall, the most consistent and important predictor for adopting EM and CSR practices was the location of the firm. This variable turned out more often to be statistically significant in explaining the differences between the perceptions on adopting EM and CSR practices. Several interesting findings have been revealed that link the independent variables (number of employees, turnover and geographical location) with the examined motivations for adopting EM and CSR practices, pressures from various stakeholders, and the various environmental targets and methods.

More analytically, as regards the pressures for employing EM practices, the analysis showed that the size of the SME is an important factor when it comes to pressures from the parent company 
and from customers, regardless of the geographical location. This divergence in managers' responses is due to the fact that managers in larger SMEs tend to consider pressure from parent company and from customers more important than managers who are engaged in smaller sized firms. On the other hand, location is important when the pressure comes from competitors and other pressure groups (Table 3). The source of this divergence is due to the fact that managers in small sized firms which operate in a developing country tend to consider pressure from competitors as a more important factor than managers in firms which operate in a developed country. Motivations for EM practices, such as improved working conditions are also different for UK and Indian SMEs. This statistically significant difference is a product of three opinion divergences. Small and large Indian SMEs consider improved working conditions more important than the corresponding British SMEs as in the UK working conditions are generally good by default. The opposite holds for the medium-sized SMEs, where the British SMEs are rank higher the motivation of improved working conditions.

Next we turn to the question of whether or not SMEs' CSR practices vary with turnover and its interaction with the geographical location. Recent literature has already identified financial performance to have a significant positive relationship with CSR (Jain et al., 2016; Nejati et al., 2016; Weber, 2008). This positive association has been identified as both direct and indirect, through the ability of those organizations that adopt CSR practices to manage their stakeholders (Madueño et al., 2016). In another study, Stoian and Gilman (2017) empirically show that CSR activities enhance business growth, by utilizing a logistic regression approach using data on 211 UK SMEs.

Results of Table 4 revealed that pressure from pressure groups is dependent on both turnover and location. This statistically significant difference has occurred due to the fact that managers in firms which operate in India and have turnover less than a million tend to consider pressure groups as a more important factor than managers in the UK. However, managerial personnel who work for large firms (i.e. with turnover more than 50 million) in the UK evaluates pressure groups more positively than their colleagues in India.

In addition, SMEs' location is important, regardless of the SME's turnover and size, regarding the motivation of satisfying legislation. This opinion diversification is consistent and verifies the previous literature stating that developing country governments tend to be more concerned 
with the promotion of economic development than environmental or social protection in comparison to developed countries (Prieto-Carron et al., 2006). Especially for India, Tewari and Pillai (2005) attribute this behavior to the fact that the central government traditionally does not take a strong lead in enforcing environmental laws within the country. Additionally, there are cases where Indian courts have directed the (at least temporarily) close down of polluting companies; however, these orders have often not been executed by local enforcement agencies (Kennedy, 2006).

The geographical location is the main factor for differences on the CSR practices questions (Table 6). Indeed, the level of adopting CSR practices for the firm image varies both for size and location of the SME. This difference can be attributed to the fact that managers of small corporations in developing countries have a more negative attitude towards firm image compared to small firms in a developed country. Specifically, managerial personnel in India who work in large-sized firms consider firm image an important aspect compared to their colleagues in the UK. These results are in line with previous research that found differences in SMEs for participating in CSR activities, according to their size (Udayasankar, 2007); however, the current study identifies that the size differences are interacting with different location and cultural settings. Similarly, firms with 100 to 250 employees in India tend to consider pressure from customers more important than firms of the same size in the UK. The same pattern prevails for managers in India and the UK regarding the importance of pressure which stems from competitors. On the other hand, there are cases where size of firm is the only dominant factor, i.e. when considering pressures from parent company.

Finally, by examining the effects of turnover by geographical location of SMEs, with respect to CSR practices, in most of the examined cases of CSR practices the location has been found to be statistically significant. For instance, levels of pressure from competitors vary for both turnover and location of the firm (Table 7). This difference is because managers in India who are engaged in corporations with turnover between 10 and 50 million typically consider that construct more important than the UK managers. 


\subsection{Practical Implications}

This information is quite useful for client organizations to develop their sustainable supply chain strategies. While selecting suppliers they can predict the likely characteristics of suppliers in specific geographic locations with specific number of employees and turnover. SME owners / managers might develop business strategies accordingly in order to remain ahead of competition through superior EM and CSR practices. This could make them more sustainable by most appropriate trade off among economic, environmental and social criteria. Additionally, the results are beneficial to policymakers as this information enables them to plan both capital and revenue budgets to make SMEs in their region sustainable.

In summary, theoretically the current study contributes knowledge on SMEs motivation, pressure, targets and methods for adopting EM and CSR practices and correlation between SMEs EM and CSR constructs with employee number, turnover and geographical location. Practically, the outcomes of this research facilitate both policymakers and individual SMEs to make decisions for adopting EM and CSR practices that could potentially enhance their business performance.

Nevertheless, the study has limitations which highlight areas for further research. In particular, this study ignores a vital variable (industry type) that could have added further value to the current study. However, this has been kept beyond the scope of this study due to the limitation of data availability. In this research, we consider only manufacturing and process industries. Additionally, we did not analyze any environmental and social performance information, and the effect of specific variables (e.g. ISO 14000, energy efficiency targets, type resource usage) on EM and CSR practices and performance was not considered.

\section{Conclusions}

The association of SMEs' number of employees, turnover and geographical location with EM and CSR practices is unique and assists in decision-making for optimum supply chain design and operations. Moreover, derivations of the perceptions of the SMEs' experienced managerial staff on EM and CSR practices in both the countries are quite unique and have strong practical significance. 
Whilst our study results are not representative of all SMEs they do highlight areas for policymakers and government bodies to focus on making improvements. Thus, on one hand our results call for improving the sustainability practices of SMEs covering both environmental and social practices and on the other hand provide information to all involved beneficiaries. Specifically, individual SMEs could benchmark their involvement in environmental and CSR practices in comparison to others by observing the outcomes of the current study and potentially adopt means for further improvement. The SMEs customers (i.e. OEMs/retailers/public sector units) could take away the knowledge on their SMEs' environmental and CSR practices to make appropriate decisions upon selecting their supply chain partners. Moreover, this study could inform the policymakers on the basic characteristics of environmental and CSR practices of SMEs, in order to facilitate their improvement through additional resources. Furthermore, suppliers of SMEs are expected to gain knowledge on their SME customers related to their involvement with CSR practices, enabling the former to practice green supply chain operations. Finally, this study will contribute to the public awareness of EM and CSR practices of SMEs. This will also help other sectors to formulate their strategies and policies.

Lastly, as mentioned before, this study is limited to a single industry type, the one of manufacturing and processing, due to the lack of more diverse data. As such, generalizations made in this study may not be appropriate for other business sectors of SMEs. Construction industry could be a very good candidate for future study as this industry is equally vulnerable with respect to environmental and social impact. Our study is limited to two geographical locations - West Midlands in the UK and West Bengal in India. Although there are a few synergies of both the locations, the biasness could not be avoided completely. Therefore, one needs to undertake research across varied regions in order to generalize the findings. Sample size is also another limitation of the study along with the perceptional survey method and consideration of limited constructs. Hence, further study could be undertaken using more robust constructs. Additionally, we would have used more sophisticated statistical method like structural equation modelling, which would have allowed us to reveal more insights of the analysis with additional findings. Therefore, a potential research that could be undertaken using the outputs of this research is to study the effect of external pressure, motivation, and use of various methods and techniques of EM and CSR adoption on sustainability performance. 
Also, future research could be undertaken towards enriching the set of potential explanatory variables for EM and CSR practices, such as variables related to environmental and social performance impacts. 


\section{References}

1. Aragón-Correa, J.A., Hurtado-Torres, N., Sharma, S., García-Morales, V.J., 2008. Environmental strategy and performance in small firms: A resource-based perspective. J. Environ. Manage. 86, 88-103.

2. Biondi, V., Iraldo, F., Meredith, S., 2002. Achieving sustainability through environmental innovation: the role of SMEs. Int. J. Technol. Manag. 612-626.

3. Castka, P., Balzarova, M.A., Bamber, C.J., Sharp, J.M., 2004. How can SMEs effectively implement the CSR agenda? A UK case study perspective. Corp. Soc. Resp. Env. Ma. 11(3), 140-149.

4. Chileshe, N., Rameezdeen, R., Hosseini, M.R., Lehmann, S., Udeaja, C., 2016. Analysis of reverse logistics implementation practices by South Australian construction organisations. Int. J. Oper. Prod. Man. 36(3), 332-356.

5. Ciliberti, F., Pontrandolfo, P., Scozzi, B., 2008. Investigating corporate social responsibility in supply chains: a SME perspective. J. Clean. Prod. 16(15), 1579-1588.

6. Commission Recommendation, 2003. Commission Recommendation of 6 May 2003 concerning the definition of micro, small and medium-sized enterprises. Available at: http://eur-lex.europa.eu/eli/reco/2003/361/oj

7. Confederation of Indian Industry, 2013. Handbook on Corporate Social Responsibility in India.

8. Development, W.B.C. for S., 1999. Corporate Social Responsibility: Meeting Changing Expectations, World Business Council for Sustainable Development.

9. Dobson, A.J., Barnett, A., 2008. An introduction to generalized linear models. CRC press.

10. Elcio, M., Tachizawa, E. M., Gimenez, C., Sierra, V., 2015. Green supply chain management approaches: drivers and performance implications. Int. J. Oper. Prod. Man. 35(11), 15461566.

11. Environment Agency, 2002. 2002 NetRegs Benchmarking Survey, How green are small businesses?

12. Faraway, J.J., 2005. Extending the linear model with R: generalized linear, mixed effects and nonparametric regression models. CRC press.

13. Frane, A., 2015. Power and Type I Error Control for Univariate Comparisons in Multivariate Two-Group Designs. Multivariate Behav. Res. 50(2), 233-247

14. Gadenne, D.L., Kennedy, J., McKeiver, C., 2009. An empirical study of environmental awareness and practices in SMEs. J. Bus. Ethics. 84(1), 45-63.

15. Graafland, J., Van de Ven, B., Stoffele, N., 2003. Strategies and instruments for organising CSR by small and large businesses in the Netherlands. J. Bus. Ethics. 47(1), 45-60. 
16. Hsu, C., Tan, K., Hanim, S., Zailani, M., 2016. Strategic orientations, sustainable supply chain initiatives, and reverse logistics: Empirical evidence from an emerging market. Int. J. Oper. Prod. Man. 36(1), $86-110$.

17. IBM Corp. Released, 2012. IBM SPSS Statistics for Windows, Version 21.0. Armonk, NY: IBM Corp.

18. Jain, P., Vyas, V., Chalasani, D.P.S., 2016. Corporate Social Responsibility and Financial Performance in SMEs: A Structural Equation Modelling Approach. Global Business Review. 17 (3), 630-653.

19. Johnson, M.P., S. Schaltegger. 2016. Two decades of sustainability management tools for SMEs: How far have we come? J Small Bus Manage. 54 (2), 481-505.

20. Kennedy, L. (2006). Improving environmental performance of small firms through joint action: Indian tannery clusters", in Blackman, A. (Ed), Small Firms and the Environment in Developing Countries -Collective Action and Collective Impacts, RFF Press, Washington, DC, pp. 112-128.

21. Lawrence, S.R., Collins, E., Pavlovich, K., Arunachalam, M., 2006. Sustainability practices of SMEs: the case of NZ. Bus. Strat. Environ. 15(4), 242-257.

22. Lee, S.-Y., R. D. Klassen. 2008. Drivers and Enablers That Foster Environmental Management Capabilities in Small- and Medium-Sized Suppliers in Supply Chains. POMS. $17,573-586$.

23. Li, N., Toppinen, A., M. Lantta. 2016. Managerial perceptions of SMEs in the wood industry supply chain on corporate responsibility and competitive advantage: Evidence from China and Finland. J Small Bus Manage. 54 (1), 162-186.

24. Longo, M., Mura, M., Bonoli, A., 2005. Corporate social responsibility and corporate performance: the case of Italian SMEs. Corp. Govern. 5(4), 28-42.

25. Longoni, A., Cagliano, R., 2015. Environmental and social sustainability priorities: Their integration in operations strategies. Int. J. Oper. Prod. Man. 35(2), 216 - 245.

26. Madden, K., W. Scaife and K. Crissman. 2006. How and Why Small to Medium Size Enterprises (SMEs) Engage with Their Communities: An Australian Study. Int. J. Nonprofit Volunt. 11, 49-60.

27. Masurel, E., 2007. Why SMEs invest in environmental measures: sustainability evidence from small and medium-sized printing firms. Bus. Strat. Environ. 16(3), 190-201.

28. Madueño, J. H., Jorge, M. L., Conesa, I. M., D. Martínez-Martínez. 2016. Relationship between corporate social responsibility and competitive performance in Spanish SMEs: Empirical evidence from a stakeholders' perspective. BRQ. 19 (1), 55-72.

29. Nejati, M., Quazi, A., Amran, A. N. H. Ahmad. 2016. Social responsibility and performance: Does strategic orientation matter for small businesses? J Small Bus Manage. DOI:10.111/jsbm.12305. 
30. NetRegs SME Environment surveys, 2014. NetRegs, Environmental Guidance For Your Business in Northern Ireland and Scotland.

31. Piercy, N., Rich, N., 2015. The relationship between lean operations and sustainable operations. Int. J. Oper. Prod. Man. 35(2), 282-315.

32. Pil, F. K., S. Rothenberg. 2003. Environmental performance as a driver of superior quality. POMS. 12, 404-415.

33. Prieto-Carron, M., Lund-Thomsen, P., Chan, A., Muro, A., C. Bhushan. 2006. Critical perspectives on CSR and development: what we know, what we don't and what we need to know. Int. Aff. 82 (5), 977-987.

34. Raynard, P., Forstater, M., 2002. Corporate social responsibility: Implications for small and medium enterprises in developing countries (available at: http://www.unido.org/fileadmin/import/userfiles/puffk/corporatesocialresponsibility.pdf)

35. Revell, A., Blackburn, R., 2007. The business case for sustainability? An examination of small firms in the UK's construction and restaurant sectors. Bus. Strat. Environ. 16(6), 404420.

36. Stoian, C., M. Gilman. 2017. Corporate Social Responsibility That "Pays": A Strategic Approach to CSR for SMEs. J Small Bus Manage. 55 (1), 5-31.

37. Tewari, M., P. Pillai. 2005. Global standards and the dynamics of compliance in the Indian leather industry. Oxf. Dev. Stud. 33 (2), 245-267.

38. Tung, A., Baird, K., Schoch, H., 2014. The relationship between organisational factors and the effectiveness of environmental management. J. Environ. Manage. 144, 186-196.

39. Udayasankar, K. 2007. Corporate Social Responsibility and Firm Size. J. Bus. Ethics. DOI 10.1007/s10551-007-9609-8.

40. Weber M. 2008. The business case for corporate social responsibility: A company-level measurement approach for CSR. EMJ. 26 (4), 247-261.

41. Williamson, D., Lynch-Wood, G., 2001. A new paradigm for SME environmental practice. TQM magazine. 13(6), 424-433.

42. World Business Council for Sustainable Development (WBCSD)., 1999. Corporate Social Responsibility. WBCSD: Geneva.

43. Worthington, I., Ram, M., Jones, T., 2006. Exploring corporate social responsibility in the UK Asian small business community. J. Bus. Ethics. 67(2), 201-217.

44. Zorzini, M., Hendry, L.C., Huq, F.A., Stevenson, M., 2015. Socially responsible sourcing: reviewing the literature and its use of theory. Int. J. Oper. Prod. Man. 35(1), 60-109. 


\section{APPENDIX A}

Table A1: EM and CRS practices constructs and proxies.

\begin{tabular}{llll}
\hline \multicolumn{1}{c}{ Motivation } & \multicolumn{1}{c}{ Pressure } & \multicolumn{1}{c}{ Targets } & \multicolumn{1}{c}{ Methods } \\
\hline & & & \multicolumn{1}{c}{ Environmental } \\
& & audit \\
Firm image & Parent company & Raw & Recycling program \\
Market opportunities & Shareholders & materials & Environmental \\
Moral duty & Employees & Waste & management \\
Business strategy & Customers & Energy & system (ISO14000) \\
Satisfying legislation & Competitors & Water & Eco-management \\
Employee satisfaction & Government & Emission & and audit scheme \\
Economic benefit & NGOs & to air & Staff training on \\
Operational efficiency & & & environmental \\
& & & practices \\
& & & Formal reporting \\
\hline
\end{tabular}




\section{APPENDIX B}

Table B1: Summary of survey questions and types of responses gathered. References are provided for studies that have been conducted using similar survey questions.

\begin{tabular}{|c|c|c|}
\hline $\begin{array}{l}\text { Survey } \\
\text { questions }\end{array}$ & Description and required response & Refs. \\
\hline $\begin{array}{l}\text { Does your } \\
\text { company } \\
\text { consider your } \\
\text { impact on the } \\
\text { environment } \\
\text { and consider } \\
\text { itself to be } \\
\text { socially and } \\
\text { ethically } \\
\text { responsible? If } \\
\text { so, what are } \\
\text { the motivating } \\
\text { factors, and if } \\
\text { not, why? }\end{array}$ & $\begin{array}{l}\text { After an initial yes/no response, a weighted response on a } \\
\text { scale of } 0 \text { to } 5,0 \text { not important, } 5 \text { extremely important, is } \\
\text { required to outline the motivations for saying yes or no. If } \\
\text { yes, is it for firm image, market opportunity, moral duty, } \\
\text { business strategy, meeting legislation, improved conditions, } \\
\text { economic benefit or operational efficiency? Further to this, is } \\
\text { it because of pressure received from different sources such as } \\
\text { parent companies, shareholders, employees, customers, } \\
\text { competitors, governments or other pressure groups? If an } \\
\text { SME is not considering the environment or CSR, is it } \\
\text { because of a lack of time, no economic benefit, no business } \\
\text { benefit, no interest, insufficient knowledge or perceive } \\
\text { company to have no impact? }\end{array}$ & $\begin{array}{l}\text { (Lawrence et al., } \\
\text { 2006, Masurel, } \\
\text { 2007, NetRegs } \\
\text { SME Environment } \\
\text { surveys, 2014, } \\
\text { Revell and } \\
\text { Blackburn, 2007) }\end{array}$ \\
\hline $\begin{array}{l}\text { Do you have } \\
\text { usage or } \\
\text { saving targets? }\end{array}$ & $\begin{array}{l}\text { Either a yes/no response on whether a company has targets } \\
\text { for raw material usage, waste generated, energy and water } \\
\text { used and emissions to air. }\end{array}$ & $\begin{array}{l}\text { (Lawrence et al., } \\
\text { 2006, NetRegs } \\
\text { SME Environment } \\
\text { surveys, 2014) }\end{array}$ \\
\hline $\begin{array}{l}\text { What practices } \\
\text { are being } \\
\text { implemented } \\
\text { for monitoring } \\
\text { and measuring } \\
\text { environmental } \\
\text { and social } \\
\text { performance? }\end{array}$ & $\begin{array}{l}\text { Are SMEs using environmental audits, a recycling program, } \\
\text { environment management systems (such as ISO 14001), eco- } \\
\text { management and audit schemes, staff training on } \\
\text { environmental practices and formal reporting procedures? } \\
\text { Are SMEs joining environmental group? For CSR, are SMEs } \\
\text { having ISO certifications (ISO 9001), ethics committees, } \\
\text { ethical training, code of conduct statements, annual social } \\
\text { reports, supplier audits or some form of other social } \\
\text { management systems? }\end{array}$ & $\begin{array}{l}\text { (Graafland et al., } \\
\text { 2003, Lawrence et } \\
\text { al., 2006, NetRegs } \\
\text { SME Environment } \\
\text { surveys, 2014, } \\
\text { Williamson and } \\
\text { Lynch-Wood, } \\
\text { 2001) } \\
\text { Elcio et al. } 2015\end{array}$ \\
\hline $\begin{array}{l}\text { Awareness of } \\
\text { environmental } \\
\text { issues by } \\
\text { SMEs }\end{array}$ & $\begin{array}{l}\text { A yes or no answer is provided on whether they believe that } \\
\text { their SME impacts the environmental and climate change. }\end{array}$ & \\
\hline $\begin{array}{l}\text { Level of } \\
\text { agreement } \\
\text { with } \\
\text { statements on } \\
\text { CSR }\end{array}$ & $\begin{array}{l}\text { To establish SMEs' perceptions of CSR, a series of } \\
\text { statements are used to determine whether they agree or } \\
\text { disagree (on a scale of 1-5). The following statement are } \\
\text { used: My organisation is aware of its social responsibilities, } \\
\text { business success is linked to CSR, CSR is equally important } \\
\text { as profits, CSR should be integrated into core organisational } \\
\text { strategies, customers are interested in our CSR, SMEs cannot } \\
\text { afford to be socially responsible and SMEs cannot impact } \\
\text { society. }\end{array}$ & $\begin{array}{l}\text { (Ciliberti et al., } \\
\text { 2008, Longo et al., } \\
\text { 2005) }\end{array}$ \\
\hline $\begin{array}{l}\text { How are SME } \\
\text { getting } \\
\text { involved with } \\
\text { CSR? }\end{array}$ & $\begin{array}{l}\text { To establish the types of CSR activities and level of } \\
\text { involvement, companies respond with a yes/no statement for } \\
\text { doing charitable donations, working with educational } \\
\text { institutes, investing in deprived areas, being responsible for } \\
\text { the well-being and health of staff, ethical purchasing and } \\
\text { investment, supporting communities, encouraging staff skill } \\
\text { development, infrastructure development and local } \\
\text { sponsorship. }\end{array}$ & $\begin{array}{l}\text { (Graafland et al., } \\
\text { 2003, Worthington } \\
\text { et al., 2006) }\end{array}$ \\
\hline
\end{tabular}




\section{APPENDIX C}

\section{Environmental and social performance of Small and Medium Sized Enterprises} (SMEs) in India and the UK

The below survey has been developed for distribution to SMEs in the UK and India as part of a UK - India Education and Research Initiative (UKIERI). We kindly ask for your assistance with our investigations into the current state of $(A)$ environmental practices and awareness of climate changes issues within SMEs and (B) Corporate Social Responsibility (CSR) in SMEs.

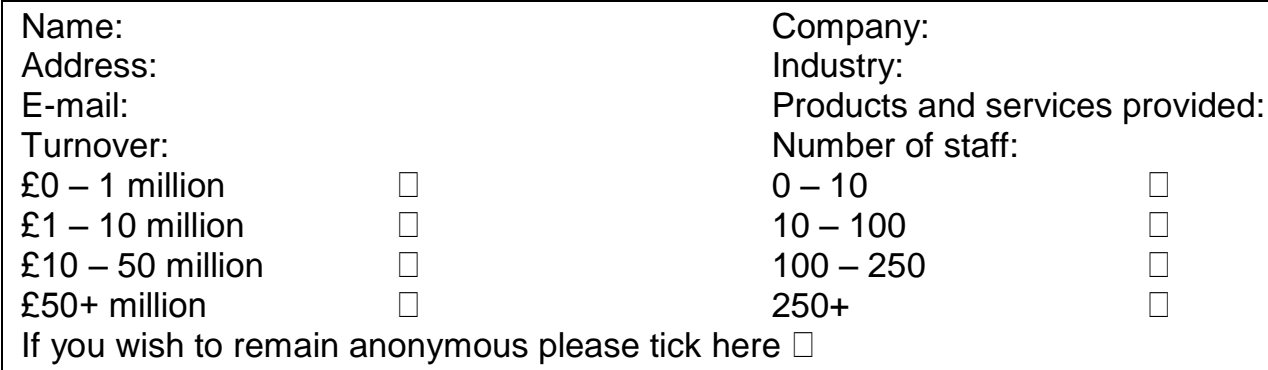

Part A: Climate change issues and environmental performance of SMEs

\section{A-1. Does your company consider its impact on the environment and climate change? \\ Yes / No}

If yes, does your organisation for the following reasons (please rate on a scale of 0 to 5,0 not important, 5 extremely important):

Firm image

0123345

Market opportunities

$0 \begin{array}{lllllll}0 & 1 & 2 & 3 & 4 & 5\end{array}$

Moral duty

$0 \begin{array}{lllllllll}0 & 1 & 2 & 3 & 4 & 5\end{array}$

Business strategy

Satisfying legislation (rules and regulations)

$\begin{array}{llllllllll}0 & 1 & 2 & 3 & 4 & 5\end{array}$

Improved working conditions (safety, cleanliness)

$\begin{array}{llllll}0 & 1 & 2 & 3 & 4 & 5\end{array}$

Economic benefit

$\begin{array}{llllll}0 & 1 & 2 & 3 & 4 & 5\end{array}$

Operational efficiency

$\begin{array}{llllll}0 & 1 & 2 & 3 & 4 & 5\end{array}$

Pressure from:

$0 \begin{array}{lllll}0 & 1 & 2 & 3 & 4\end{array}$

Parent company

012345

Shareholders

$\begin{array}{llllll}0 & 1 & 2 & 3 & 4 & 5\end{array}$

Employees

$\begin{array}{llllll}0 & 1 & 2 & 3 & 4 & 5\end{array}$

Customers

$\begin{array}{llllll}0 & 1 & 2 & 3 & 4 & 5\end{array}$

Competitors

$\begin{array}{llllll}0 & 1 & 2 & 3 & 4 & 5\end{array}$

Government

$\begin{array}{llllll}0 & 1 & 2 & 3 & 4 & 5\end{array}$

Pressure groups

If no, is it for any of the following reasons:

Lack of time

0123345

No economic benefit

0123245

No business benefit

$0 \begin{array}{lllll}0 & 1 & 2 & 3 & 4\end{array}$

No interest

012345 
Insufficient knowledge

Perceive company to have no impact on the environmental

Further comments:

A-2. Do you have usage or saving targets for the following?

Raw materials

Yes / No

Waste

Yes / No

Energy

Yes / No

Water

Yes / No

Emissions to air

Yes / No

If yes to any of the above, do you involve your suppliers in your environmental performance targets?

Yes / No

Further comments:

A-3. Do you have any of the following?

Environmental audits

Yes / No

Recycling program

Yes / No

Environment management system (ISO 14001)

Yes / No

EMAS (Eco-Management and Audit Scheme)

Yes / No

Staff training on environmental practices

Yes / No

Formal reporting

Yes / No

Further comments:

A-4. Are you part of an environmental group?

Yes / No

Further comments:

A-5. Do you consider your company to have a good awareness of the environment and climate change issues?

Yes / No

Please provide any additional information:

(e.g. frameworks adopted by your company for environmental monitoring or relevant legislation to your business's environmental practices) 


\section{Part B: Corporate social responsibility in SMEs}

B-1. Please indicate whether you strongly disagree '1', neither agree nor disagree ' 3 ', or extremely agree ' 5 ' with the following statements:

My organisation is aware of its social responsibilities

12345

Business success is linked to CSR

12345

CSR is equally important as profits

123345

CSR should be integrated into core organisational strategies

12345

Customers are interested in our CSR

12345

SMEs cannot afford to be socially responsible

123345

SMEs cannot impact society

12345

Further comments:

B-2. Do you consider your company to be socially and ethically responsible?

Yes/No

If yes, are you for any of the following reasons (please rate on a scale of 0 to 5,0 not important, 5 extremely important):

Firm image

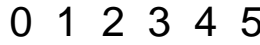

Market opportunities

$0 \begin{array}{llllll}0 & 1 & 2 & 3 & 4 & 5\end{array}$

Moral duty

$\begin{array}{lllllll}0 & 1 & 2 & 3 & 4 & 5\end{array}$

Business strategy

$\begin{array}{llllll}0 & 1 & 2 & 3 & 4 & 5\end{array}$

Satisfying legislation (rules and regulations)

$\begin{array}{llllll}0 & 1 & 2 & 3 & 4 & 5\end{array}$

Employee satisfaction

$\begin{array}{llllll}0 & 1 & 2 & 3 & 4 & 5\end{array}$

Economic benefit

$\begin{array}{lllllll}0 & 1 & 2 & 3 & 4 & 5\end{array}$

Operational efficiency

012345

Pressure from:

Parent company

Shareholders

0123345

Employees

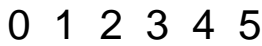

Customers

$\begin{array}{llllll}0 & 1 & 2 & 3 & 4 & 5\end{array}$

Competitors

$\begin{array}{llllll}0 & 1 & 2 & 3 & 4 & 5\end{array}$

Government

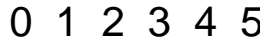

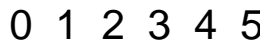

Pressure groups

If no, is it for any of the following reasons:

Lack of time

012345

No economic benefit 
No business benefit

No interest

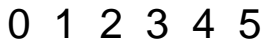

Insufficient knowledge

Further comments:

B-3. How is your organisation involved with CSR?

Charitable donations

Yes/No

Working with educational institutes

Yes/No

Investments in deprived areas

Yes/No

Responsibility for well being and health of staff

Yes/No

Ethical purchasing and investment

Yes/No

Supporting involvement with communities

Yes/No

Encouraging staff skill development

Yes/No

Infrastructure development

Yes/No

Local sponsorship

Yes/No

Other (please provide details)

Yes/No

Further comments:

B-4. Do you have any of the following for monitoring CSR performance?

ISO certification (e.g. 9001)

Yes/No

Ethics committee

Yes/No

Ethical training

Yes/No

Code of conduct

Yes/No

Annual social reports

Yes/No

Supplier audits

Yes/No

SA8000

Yes/No

Other social management system

Yes/No

Further comments:

B-5. Please provide details of any legislation relevant to CSR in your organisation. 